\title{
Advisers rebel over choice of museum chief
}

Alison Abbott, Munich

The head of the scientific advisory board of the Deutsches Museum - one of the world's largest science museums - has resigned in protest at the selection procedure for the museum's new director.

Jürgen Renn, chairman of the board and a director at the Max Planck Institute for the History of Science in Berlin, says the museum's administrative council ignored the board's input when it made the appointment in August. Two other board members have resigned, and the remaining seven have expressed concerns about the selection process.

Board members stress that they have no quarrel with Wolfgang Heckl, the physicist who took up the director's position on 1 October (see Nature 431, 612; 2004). Renn says, for example, that Heckl "certainly has the communication skills that are needed to run the museum".

But they say that the administrative council failed to seek their opinion when making its decision."The administrative council took no account of other factors required for leadership of such a museum particularly experience with museums or the history of science," Renn says. He adds that the council did not make its selection methods and criteria clear.

Wolfgang Herrmann, president of the Technical University of Munich and head of the administrative council, says the procedure was "as transparent as it needed to be". The administrative council is solely responsible for selecting the candidate, and

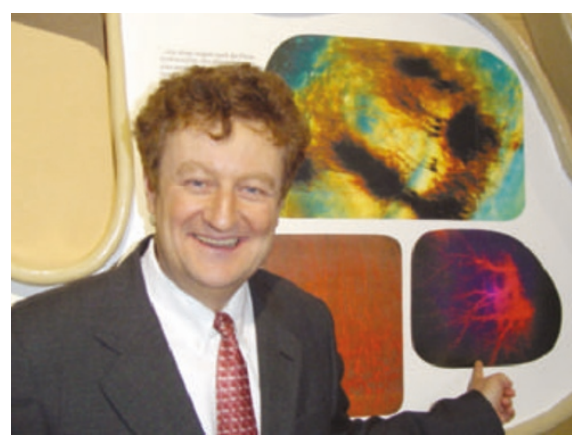

Wolfgang Heckl: his appointment as director of Munich's science museum has raised hackles.

was glad to receive input from its scientific advisory board. "But the scientific panel had a different opinion to that of the administrative council - this happens sometimes," says Herrmann.

Paolo Galluzzi, a board member and head of the Science Museum in Florence, says he supports Renn's decision to quit. Galluzzi says he decided not to resign himself because

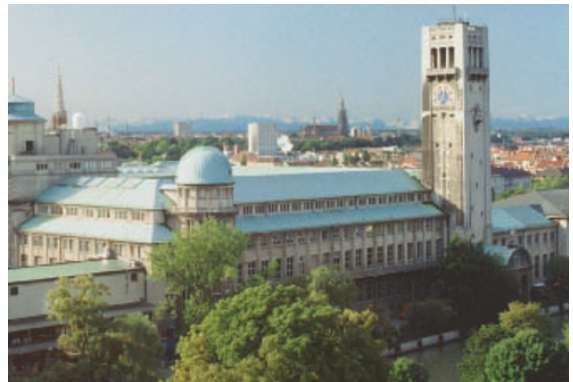

Deutsches Museum: consolidating its research. he "doesn't want to weaken the scientific advisory structure further". But he adds that the remaining panel members are prepared to resign unless they receive assurances from the administrative council that their advice will be listened to in future.

Jochen Brüning, another board member and a mathematician at Humboldt University in Berlin, where he curates a museum collection, says he wants to give the new director as much support as possible. $\mathrm{He}$ adds: "It would be tragic if some new way was not found to have an effective external scientific advisory structure."

Most of the $€ 33$ million (US $\$ 40$ million) in annual funding for the Deutsches Museum comes from the Bavarian government and the German federal government. Almost one-third of it is spent on research.

The museum fared badly, however, in a 1998 external evaluation. Helmut Trischler, a science historian and the museum's head of research, says that the museum has been steadily consolidating its research since then, and won a strong endorsement in a 2002 evaluation. "The scientific advisory board worked hard in helping us root research more strongly within the museum as a whole, and we have implemented some of their suggestions," says Trischler.

Heckl says he is disturbed by the furore over his appointment, but reassured by the expressions of personal goodwill from the scientific advisory board. He points out that he does have experience of running exhibitions - one of them was shown in the Deutsches Museum itself in 2001.

\section{Paris collections snubbed in spending review}

\section{Sally Goodman, Paris}

Researchers at France's National Museum of Natural History are growing worried about the future of their collections, after this summer's government spending review failed to earmark any money to maintain them.

In July, France's research and environment ministries agreed to increase their joint annual contribution to the Paris museum's upkeep from $€ 12$ million (US\$15 million) to $€ 19$ million. But they did not include any cash for the collections, which - with around 65 million specimens - are among the most extensive in the world.

Museum staff claim that the omission occurred because the government's scientific advisers do not value taxonomy, or understand its importance to biodiversity research. President Jacques Chirac, however, has identified biodiversity as one of his top research priorities, and is backing an international meeting on the subject in Paris next January.

The lack of funding for the collections is "scandalous", complains Simon Tillier, head of the museum's department of systematic biology and evolution.

Despite the lack of government backing, the museum's director, Bertrand-Pierre Galey, says he plans to develop the collections, starting next year with the modernization of the world's largest herbarium. There are also plans to move the palaeontology collection from its current basement home, where it is at risk of flooding, and to continue a project to digitally catalogue the collections. But the museum will now have to fund these projects at the expense of other activities - such as research - or else find private backing for them.
Staff at the museum say that morale has been improving of late, after a restructuring reduced the power of senior professors and reorganized the museum's 26 laboratories into 7 research departments. But researchers are complaining that a lack of resources for maintaining the collections will render specimens difficult to access and vulnerable to deterioration.

Yvon Le Maho of the Paris museum's scientific advisory board believes the situation reflects a growing rift in modern biology. "The study of whole organisms and populations is seen as second-rate science compared with molecular biology, but you cannot dissociate the two," he says.

The Parisian curators say they are hoping for more support for their collections from the government when it reviews the museum's operating contract in two years' time. 